\title{
PENGARUH MODEL PEMBELAJARAN CONNECTED MATHEMATIC PROJECT TERHADAP KEMAMPUAN PEMECAHAN MASALAH MATEMATIKA
}

\author{
Witri Lestari \\ Program Studi Pendidikan Matematika, \\ FTMIPA, Universitas Indraprasta PGRI Jakarta.
}

\begin{tabular}{l}
\hline INFO ARTICLES \\
\hline Article History: \\
Received: 03-04-2017 \\
Revised: 10-04-2017 \\
Approved: $17-04-2017$ \\
Publish Online: 18-06-2017 \\
\hline Key Words: \\
Connected Mathematics Project \\
Learning Method, Mathematics \\
Problem Solving Skills. \\
\\
cC) (†) (9) \\
\hline EY
\end{tabular}

\begin{abstract}
The purpose of the research is to determine the Impacts of Connected Mathematics project Learning Method on Student's Mathematics Problem solving Skills at SMP Putra Bangsa. The research method is experiment. Sample of the research is taken from affordable population by using cluster random sampling technique. Size of population is 40 students that divided into two class. The instrument used is essay test as much as 6 items. Analysis technique in this research is $t$ test. Testing requirements of data analysis is Liliefors test for normality and fisher test for homogeneity test. In experiment class L test $=$ 0.1143 and $\mathrm{L}$ table $=0.190$. in control class $\mathrm{L}$ test $=0.0868$ and $\mathrm{L}$ table $=0.190$, because $\mathrm{L}$ test $<\mathrm{L}$ table, so Ho is received and it can be concluded that the data of the population in normal distribution. $\mathrm{F}$ test for homogeneity , $\mathrm{F}$ test $=1.826$ and $\mathrm{F}$ table $=2.17$, because $\mathrm{F}$ test $<\mathrm{F}$ table, so both of class has same varians or homogen. The result of data analyze $t$ test $=3.16$ and $t$ table $=2.03$ at significance level $\alpha=0.05$ and freedom degrees $=38$, so there are impacts of connected mathematics project learning model on mathematics problem solving skills.
\end{abstract}

\begin{abstract}
Abstrak: Tujuan dari penelitian ini adalah untuk mengetahui pengaruh model pembelajaran connected mathematic project terhadap kemampuan pemecahan masalah matematika pada siswa di SMP Putra Bangsa. Metode penelitian adalah metode eksperimen. Sampel penelitian ini diambil populasi terjangkau dengan teknil cluster random sampling. Besar sampel sebanyak 40 siswa, yang dibagikan menjadi 2 kelas, instrumen yang digunakan adalah tes essai sebanyak 6 butir soal. Teknik analisis yang digunakan dalam penelitian ini adalah dengan analisis uji $\boldsymbol{t}$. Uji persyaratan analisis data yang digunakan dalam penelitian ini adalah uji Liliefors untuk normalitas dan uji Fisher untuk homogenitas. Untuk kelas eksperimen di dapat $\mathrm{L}_{\text {hitung }}=0,1143$ dan $\mathrm{L}_{\text {tabel }}=0,190$. Sedangkan untuk kelas kontrol didapat $\mathrm{L}_{\text {hitung }}=0,0868$ dan $\mathrm{L}_{\text {tabel }}=0,190$. Karena $\mathrm{L}_{\text {hitung }}<$ $\mathrm{L}_{\text {tabel }}$, maka $\mathrm{H}_{0}$ diterima dan disimpulkan bahwa data sampel berasal dari populasi berdistribusi normal. Uji $\mathrm{F}$ untuk homogenitas diperoleh $\mathrm{F}_{\text {hitung }}=$ 1,826 dan $\mathrm{L}_{\text {tabel }}=2,17$, karena $\mathrm{F}_{\text {hitung }}<\mathrm{F}_{\text {tabel }}$ maka kedua kelas tersebut memiliki varians yang sama atau dinyatakan homogen. Hasil dari analisis data diperoleh harga $\boldsymbol{t}_{\text {hitung }}=3,16$ dan $\boldsymbol{t}_{\text {tabel }}=2,03$, dengan taraf signisikasi $\alpha=$ 0,05 dan derajat kebebasan $=38$ maka dapat dinyatakan terdapat pengaruh model pembelajaran connected mathematic project terhadap kemampuan pemecahan masalah matematika.
\end{abstract}

\footnotetext{
Correspondence Address: Jln. Raya Tengah Kelurahan Gedong, Pasar Rebo, Jakarta Timur, 13760, Indonesia; $e$ mail: witrilestari.unindra@gmail.com
}

How to Cite (APA $6^{\text {th }}$ Style): Lestari, W. (2017). Pengaruh Model Pembelajaran Connected Mathematic Project terhadap Kemampuan Pemecahan Masalah Matematika. JKPM (Jurnal Kajian Pendidikan Matematika), 02 (02), $245-$ 253. DOI: $10.1007 / \mathrm{XXXXXX-XX-0000-00}$

Copyright: Lestari, W. (2017)

Competing Interests Disclosures: The authors declare that they have no significant competing financial, professional or personal interests that might have influenced the performance or presentation of the work described in this manuscript. 


\section{PENDAHULUAN}

Matematika merupakan salah satu pelajaran wajib yang diajarkan mulai dari jenjang pendidikan dasar, menengah, sampai perguruan tinggi. Dalam pembelajaran matematika, semua siswa dituntut untuk menguasai semua kemampuan matematis yang diharapkan. Berdasarkan kenyataan di lapangan dan pengamatan penulis, sudah sejak lama matematika merupakan salah satu mata pelajaran yang dihindari bagi kebanyakan siswa karena dianggap mata pelajaran yang sulit dimengerti dengan banyaknya angka, simbol, rumus dan teori. Rendahnya penguasaan siswa dalam matematika juga mengakibatkan banyak timbulnya kesulitan dalam memahami dan mempelajari pelajaran matematika, sehingga siswa menjadi kurang berminat dalam mempelajarinya. Sedangkan menurut Utomo (2012:146) karena untuk menguasai matematika tidak hanya dilihat pada unitnya saja seperti aritmatika, akan tetapi ada yang lebih luas yaitu menguasai dan terampil menyelesaikan masalah dengan tahapan-tahapan tertentu (Hamzah, 2014). Hal ini juga ditegaskan oleh NCTM (National Council of Teachers Mathematics) dalam buku Principles and Standards for School Mathematics menyatakan bahwa siswa harus belajar matematika dengan pemahaman, aktif membangun pengetahuan baru dari pengalaman dan pengetahuan sebelumnya, dengan begitu siswa akan menjadi kompeten dan percaya diri akan kemampuannya untuk mengatasi masalah yang rumit dan mampu bertahan ketika ada tugas-tugas yang menantang.

Seiring dengan perubahan zaman, pola pemikiran siswa dan juga orang tua murid mulai berubah, mereka mulai menyadari pentingnya matematika dalam kehidupan sehari-hari. Tidak sedikit siswa yang mulai menyukai matematika dan mulai mendalaminya. Banyak dari mereka yang mengikuti bimbingan belajar di luar sekolah atau bahkan memanggil guru les privat agar mereka lebih intensif dalam belajar. Hal ini pun akhirnya dapat memberikan dampak positif terhadap hasil belajar siswa.

Bersamaan dengan peningkatan hasil belajar matematika tersebut masalah baru kembali muncul, kebanyakan siswa hanya mampu menghapal rumus dan langkah-langkah yang diberikan guru dalam pembelajaran, mereka tidak tahu darimana rumus itu diperoleh. Kebanyakan siswa akan mengalami kesulitan ketika diberikan masalah yang mempunyai model yang berbeda dengan contoh yang diberikan oleh guru. Hal ini kemungkinan besar terjadi karena pembelajaran di sekolah yang lebih sering berpusat pada guru dan kurang menuntut keaktifan siswa dalam pembelajaran. Pembelajaran matematika yang seharusnya diberikan adalah yang dapat menuntut keaktifan serta peran siswa dalam pembelajaran.

Siswa harus mampu mengungkapkan gagasan dan ide-ide matematis mereka. Karena dengan keaktifan serta peran siswa dalam pembelajaran, mereka dapat membangun serta memperkuat pemahaman mereka terhadap konsep-konsep matematika. Siswa perlu difasilitasi oleh guru yang mengajar di kelas agar mereka dapat mengungkapkan gaagasan dan ide-ide matematisnya untuk dapat menyelesaikan masalah yang dihadapi. Pengungkapan gagasan dan ide dapat dilakukan dengan beberapa macam cara diantaranya dengan benda kongkrit, simbol, diagram, grafik, dan tabel. Kemampuan inilah yang disebut dengan kemampuan pemecahan masalah matematika. Kemampuan pemecahan masalah matematika merupakan salah satu standar dalam National Council of Teachers of Mathematics (NCTM) untuk sekolah-sekolah yang mengajarkan matematika. Kemampuan yang termasuk standar NCTM antara lain: kemampuan penalaran dan pembuktian (Reasoning and Proof), kemampuan koneksi (Connection), kemampuan komunikasi (Communication), kemampuan representasi (Representation), dan kemampuan pemecahan masalah (Problem Solving). Kelima kemampuan tersebut saling terhubung antara yang satu dengan yang lain yang harus dikuasai oleh seorang siswa agar mampu memahami serta mengaplikasikan matematika dalam kehidupan sehari-hari.

Pemecahan masalah dalam proses belajar sangat penting, maka dari itu kebanyakan bidang studi dapat dijadikan sebagai sarana belajar pemecahan masalah. Menurut Syah (2010:121) untuk memenuhi keperluan belajar pemecahan masalah ini, guru (khususnya yang mengajar eksakta, seperti matematika dan IPA) sangat 
dianjurkan menggunakan model dan strategi mengajar yang berorientasi pada cara pemecahan masalah, tetapi dalam pelaksanaannya di lapangan kemampuan tersebut belum dapat dikembangkan secara maksimal, khususnya pada siswa tingkat SMP. Pembelajaran matematika yang sering terjadi, siswa tidak diberikan kesempatan untuk melakukan pemecahan masalah sendiri. Siswa lebih banyak mengikuti cara pemecahan masalah yang telah dicontohkan oleh guru, sehingga mereka tidak mampu mengembangkan kemampuan pemecahanan masalahnya dengan baik.

Berdasarkan pengamatan atas penelitian penulis di SMP Putra Bangsa, pembelajaran yang dilaksanakan di kelas lebih terpusat pada guru. Guru yang mendominasi pembelajaran dengan banyak menyampaikan materi melalui cara konvensional dan siswa hanya banyak mendengarkan apa yang disampaikan guru tanpa ikut aktif dalam pembelajaran. Saat penulis mencoba meminta siswa untuk menggambar (membuat pemecahan masalah dalam bentuk gambar), banyak siswa yang melakukan kesalahan walaupun pada saat itu penulis meminta pemecahan masalah yang sederhana. Hal ini menunjukan bahwa kemampuan pemecahan masalah matematika siswa di SMP Putra Bangsa masih rendah.

Data yang penulis dapatkan dari hasil wawancara kepada guru matematika kelas VII di SMP Putra Bangsa, pada dasarnya siswa sudah mendapatkan nilai yang bagus dan memahami setiap mata pelajaran, namun tidak dengan mata pelajaran matematika. Dengan hasil belajar matematika di SMP Putra Bangsa dapat dilihat pada tabel di bawah ini:

Tabel 1. Data Nilai Matematika Siswa SMP Putra Bangsa Depok

\begin{tabular}{cccc}
\hline \multirow{2}{*}{ Tahun } & \multicolumn{2}{c}{ Nilai Rata-rata Kelas VII } & \multirow{2}{*}{ KKM } \\
\cline { 2 - 3 } & Semester 1 & Semester 2 & \\
\hline $2013 / 2014$ & 63 & 60 & 75 \\
$2014 / 2015$ & 60 & 58 & 75 \\
$2015 / 2016$ & 64 & 62 & 75 \\
\hline
\end{tabular}

Sumber : Dokumen SMP Putra Bangsa Depok

Dari data di atas menunjukan bahwa nilai matematika siswa masih di bawah KKM, hal ini dikarenakan masih adanya kesulitan dalam pengerjaan dan pemahaman matematika. Untuk itu maka perlu adanya pengembangan kemampuan pemecahan masalah matematika siswa yang dapat dilakukan melalui berbagai cara, salah satunya adalah penggunaan suatu model pembelajaran yang memberikan kesempatan kepada siswa untuk mengembangkan kemampuan pemecahan masalah matematikanya. Model pembelajaran yang dimaksud adalah yang dapat memberikan kesempatan seluas-luasnya kepada siswa melalui berbagai kegiatan atau tugas yang meminta siswa untuk melakukan pemecahan masalah.

Connected Mathematics Project (CMP) adalah suatu model pembelajaran yang menekankan pada pemberian tugas yang berhubungan dengan matematika. Tujuan utama dari Connected Mathematics Project (CMP) adalah untuk membantu siswa dan guru dalam mengembangkan pengetahuan matematika, pemahaman, dan keterampilan, serta kesadaran dan apresiasi terhadap pengayaan hubungan antar bagian dalam matematika dan antara matematika dengan disiplin ilmu lainnya. Lebih lanjut lagi Lappan., dkk (2002:1) menyatakan bahwa CMP di atur sehingga siswa terus memecahkan masalah yang berisi konsepkonsep penting dalam matematika dan keterampilan matematika. Tahapan-tahapan yang terdapat pada CMP yakni launching, exploring, dan summarizing, dimana tahapan ini akan membantu siswa untuk mengasah kemampuan pemahamannya, sehingga siswa mampu untuk menyelesaikan masalah matematika. 


\section{METODE}

Metode yang digunakan dalam penelitian ini adalah metode eksperimen dengan pendekatan kuantitatif karena dalam penelitian ini variabel-variabel yang ada termasuk variabel bebas (independent variabel) dan variabel terikat (dependent variabel), sudah ditentukan secara tegas oleh peneliti sejak awal penelitian (Sukardi, 2003). Peneliti menggunakan desain posttest only control group design. Adapun desain penelitiannya digambarkan sebagai berikut:

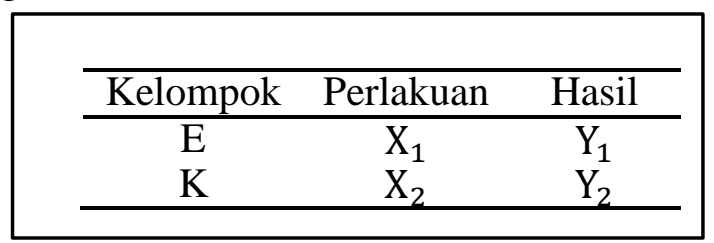

Gambar 1. Desain Penelitian

Keterangan:

E : Kelompok kelas eksperimen

$\mathrm{K}$ : Kelompok kelas kontrol

$\mathrm{X}_{1}$ : Perlakuan berupa metode brain gym

$\mathrm{X}_{2}$ : Perlakuan berupa metode structured dyadic

$\mathrm{Y}_{1}$ : Skor hasil posttest dengan soal yang sama pada kelas eksperimen

$\mathrm{Y}_{2} \quad$ : Skor hasil posttest dengan soal yang sama pada kelas kontrol

Penelitian dilakukan di Sekolah Menengah Pertama (SMP) Putra Bangsa pada siswa kelas VII semester dua (semester genap) tahun ajaran 2016/2017. Sampel pada penelitian ini sebanyak 40 siswa yang terbagi menjadi 2 kelompok yaitu kelompok eksperimen dan kontrol. Pengumpulan data dilakukan dengan cara melakukan tes pada akhir pokok bahasan setelah perlakuan diberikan berupa soal bentuk essay sebanyak 6 butir soal. Kemampuan pemecahan masalah matematika adalah skor kemampuan kognitif siswa setelah belajar matematika, di mana kemampuan siswa tersebut merupakan hasil yang diklasifikasikan ke dalam kategori tertentu yang meliputi aspek pemahaman, aplikasi, dan sintesis. Adapun tes yang akan diberikan yaitu tes essay sebanyak 6 butir soal yang sudah divalidasi secara empiris. Sebelum digunakan untuk mengumpulan data penelitian, instrumen tes hasil belajar diujicoba terlebih dahulu. Ujicoba instrumen dilakukan di kelas lain yang tidak dijadikan kelompok sampel. Adapun karakteristik instrumen: ranah kognitif $\mathrm{C} 1, \mathrm{C} 2$, dan $\mathrm{C} 3$; tingkat kesukaran dalam rentang 0,07 s.d. 0,83 meliputi soal dengan kriteria mudah, sedang, dan sukar; daya beda dalam rentang 0,06 s.d. 0,47; validitas dalam rentang 0,39 s.d. 0,46; dan reliabilitas 0,84 . Secara spesifik, pedoman penskoran untuk kemampuan pemecahan masalah matematika ditampilkan pada tabel 2. 
Tabel 2. Pedoman Penskoran untuk Kemampuan Pemecahan Masalah

Aspek yang Dinilai

Skor

A. Melihat Masalah (diisi dari isi jawaban)

1. Benar

2. Salah atau tidak ada jawaban

0

\section{B. Rencana Strategi Pemecahan Masalah (dalam bentuk} tabel atau deskripsi kalimat)

1. Benar

2. Salah atau tidak ada jawaban

3

3. Tidak membuat

C. Proses Melaksanakan Strategi Pemecahan Masalah (menghitung sampai memperoleh hasilnya)

1. Benar

2. Hampir benar

3. Yang benar dan salah seimbang

4. Sebagian kecil benar

5. Salah

6. Tidak menghitung

\section{Menjelaskan Jawaban Permasalahan}

1. Benar

2. Salah atau tidak ada

Skor minimal $=\mathbf{0}$, skor maksimal $=\mathbf{1 0}$

Sumber: Hamzah (2014:149)

\section{HASIL}

Uji Persyaratan Analisis

Karena $\mathrm{L}_{\text {hitung }}$ pada kedua kelas kurang dari $\mathrm{L}_{\text {tabel }}$ maka dapat disimpulkan bahwa data populasi kedua kelompok berdistribusi normal. Rekapitulasi hasil uji normalitas data ditampilkan pada tabel 3. Hasil perhitungan diperoleh $\mathrm{F}_{\text {hitung }}=\mathrm{I}, 826$ dan $\mathrm{F}_{\text {tabel }}=2,17$ pada taraf signifikasi $\alpha=0,05$ dengan derajat kebebasan pembilang $=19$ dan derajat kebebasan penyebut $=19$. Berdasarkan hasil tersebut, karena $\mathrm{F}_{\text {hitung }}$ lebih kecil dari $\mathrm{F}_{\text {tabel }}(1,826 \leq 2,17)$ maka $\mathrm{H}_{0}$ diterima, artinya varians data hasil penelitian dari kelas eksperimen dan kelas kontrol ini homogen. Rekapitulasi hasil uji homogenitas varians ditampilkan pada tabel 4. 
Tabel 3. Rekapitulasi Hasil Uji Normalitas Data

\begin{tabular}{ccccc}
\hline Kelas & Jumlah Sampel & $\mathrm{L}_{\text {hitung }}$ & $\mathrm{L}_{\text {tabel }}$ & Simpulan \\
\hline Eksperimen & 20 & 0,1358 & 0,190 & Normal \\
Kontrol & 20 & 0,0868 & 0,190 & Normal \\
\hline
\end{tabular}

Tabel 4. Rekapitulasi Hasil Uji Homogenitas Varians

\begin{tabular}{ccc}
\hline Statistik & Kelas Eksperimen & Kelas Kontrol \\
\hline $\mathrm{N}$ & 20 & 20 \\
Varians & 54,02 & 98,67 \\
$\mathrm{~F}_{\text {hitung }}$ & \multicolumn{3}{c}{1,826} \\
$\mathrm{~F}_{\text {tabel }}$ & \multicolumn{3}{c}{2,17} \\
Simpulan & \multicolumn{3}{c}{ Terima $\mathrm{H}_{0}$} \\
\hline
\end{tabular}

\section{Uji Hipotesis Penelitian}

Jika analisis data dalam penelitian dilakukan dengan cara membandingkan data dua kelompok sampel, atau membandingkan data antara kelas eksperimen dan kelas kontrol, atau membandingkan peningkatan data kelas eksperimen dengan peningkatan data kelas kontrol, maka dilakukan pengujian hipotesis komparasi dengan uji $\boldsymbol{t}$.

Hipotesis:

$\mathrm{H}_{0}: \mu_{1}=\mu_{2}$

$\mathrm{H}_{1}: \mu_{1} \neq \mu_{2}$

Keterangan:

$\mu_{1}=$ Rata-rata kemampuan pemecahan masalah matematika siswa pada kelompok eksperimen

$\mu_{2}=$ Rata-rata kemampuan pemecahan masalah matematika siswa pada kelompok kontrol

Untuk menguji hipotesis selisih rata-rata antara kelompok 1 dan kelompok 2 menggunakan rumus:

$\mathrm{t}=\frac{\overline{\mathrm{X}}_{1}-\overline{\mathrm{X}}_{2}}{\mathrm{SD} \sqrt{\frac{1}{\mathrm{n}_{1}}+\frac{1}{\mathrm{n}_{2}}}}$

$\mathrm{S}_{\mathrm{gab}}=\sqrt{\frac{\left(n_{1}-1\right) \mathrm{S}_{1}^{2}+\left(n_{2}-1\right) \mathrm{S}_{2}^{2}}{n_{1}+n_{2}-2}}$

Keterangan:

$\overline{\mathrm{X}}_{1}=$ rata-rata kemampuan pemecahan masalah matematika kelas eksperimen

$\overline{\mathrm{X}}_{2}=$ rata-rata kemampuan pemecahan masalah matematika kelas kontrol

$\mathrm{S}_{1}^{2}=$ varians kelas eksperimen

$\mathrm{S}_{2}^{2}=$ varians kelas kontrol

$n_{1}=$ jumlah sampel kelas eksperimen

$n_{2}=$ jumlah sampel kelas kontrol 
Uji hipotesis yang digunakan adalah uji t. Untuk lebih jelas lihat tabel 5.

Tabel 5. Rekapitulasi Uji $t$ Data Kelas Eksperimen dan Kontrol

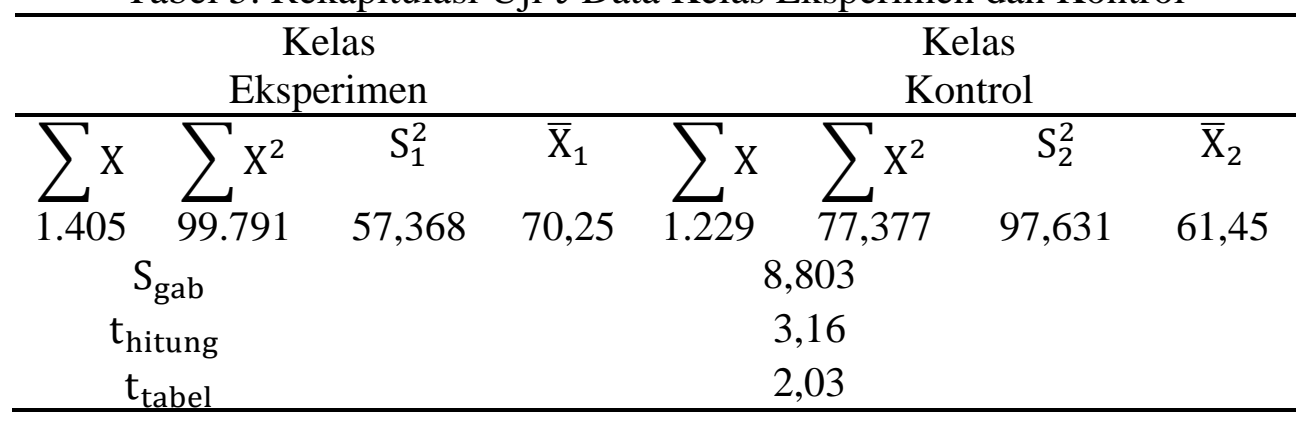

Untuk pengujian hipotesis, selanjutnya nilai $t_{\text {hitung }}$ dibandingkan dengan nilai tabel distribusi $t_{\text {tabel }}$ pada taraf signifikasi $\alpha=0,05 \mathrm{dan} \mathrm{dk}=n_{1}-n_{2}+2$. Dapat disimpulkan bahwa nilai $t_{\text {tabel }}=2,03$ dan $t_{\text {hitung }}$ $=3,16$, artinya $(3,16>2,03)$ dan kriteria hipotesis tolak $\mathrm{H}_{0}$ dan terima $\mathrm{H}_{1}$ yaitu terdapat pengaruh antara model pembelajaran Connected Mathematic Project terhadap kemampuan pemecahan masalah matematika siswa.

\section{PEMBAHASAN}

Berdasarkan hasil penelitian, maka disimpulkan terdapat pengaruh model pembelajaran connected mathematics project (CMP) terhadap kemampuan pemecahan masalah matematika di sekolah menengah pertama (SMP) Putra Bangsa". Pemecahan masalah matematika salah satu hal yang selama ini membuat siswa kesulitan, mereka kurang terampil dalam memecahkan masalah, itu dikarenakan mereka tidak banyak mencoba-coba menyelesaikannya, di awal mereka mendapatkan sebuah masalah matematika pikirannya adalah pastilah akan sulit, dan selanjutnya mereka akan bermalas-malasan.

Dalam situasi seperti ini, diperlukan adanya model pembelajaran yang tepat, untuk menekankan pada siswa supaya ikut berperan aktif agar siswa dapat lebih mengeksplorasi pemikirannya dan bergerak bebas pada saat preses belajarnya dan akan lebih baik apabila dalam pembelajaran di kelas menggunakan model pembelajaran yang baru, yakni salah satunya adalah Connected Mathematic Project (CMP). Model pembelajaran ini akan lebih memudahkan para guru dan siswa membuat matematika menjadi lebih mudah dipelajari, langkah-langkah dalam model ini pun akan membuat para siswa menjadi lebih aktif lagi dan tidak membosankan. Hal ini senada yang dikatakan oleh Rohendi (2013:18) menyatakan bahwa CMP merangsang pemahaman dari permasalahan tak langsung dengan menggunakan bentuk khusus dari representasi, seperti grafik, angka, simbol, dan verbal, lalu mendiskusikan dan mengevaluasi pemecahan dari masalah tersebut. Berdasarkan hasil penelitian yang dilakukan oleh Mulyoko (2014) bahwa pembelajaran matematika dengan menggunakan model CMP berpengaruh terhadap kemampuan representasi matematis siswa.

Penelitian ini dilaksanakan sebanyak enam kali pertemuan, lima pertemuan digunakan untuk pemberian perlakuan dan satu pertemuan digunakan untuk pemberian post test. Langkah-langkah pembelajaran Connected Mathematic Project (CMP) yang dilaksanakan pada kelas eksperimen yaitu, pada setiap pertemuannya sebelum memulai pembelajaran, siswa dibentuk dalam beberapa kelompok yang terdiri dari 4-5 orang dan diminta duduk berdasarkan kelompoknya. Pada setiap pertemuannya, kelompok dibuat berbeda-beda dengan pertemuan sebelumnya dengan memperhatikan kemampuan siswa dalam masingmasing kelompok tetap merata. Setelah siswa duduk dalam kelompoknya, setiap kelompok diberikan Lembar Kerja Siswa (LKS) yang dijadikan sebagai bahan diskusi. Model pembelajaran Connected Mathematic Project (CMP) meliputi tiga tahap atau langkah yaitu launch, explore, dan summarize. Pada 
tahap launch, siswa diberikan pertanyaan-pertanyaan yang merangsang penegetahuan siswa tentang materi yang akan dipelajari kemudian guru menyampaikan masalah yang terdapat pada Lembar Kerja Siswa (LKS) yang akan didiskusikan oleh siswa. Masalah yang diberikan berupa masalah-masalah yang menuntut siswa menggunakan berbagai bentuk pemecahan masalah matematika dalam menentukan penyelesaiannya. Hal ini bertujuan agar siswa lebih luwes dalam menggunakan berbagai macam pemecahan masalah matematika untuk mencari solusi dan memecahkan masalah yang diberikan.

Pada tahap explore, siswa berdiskusi dalam kelompok untuk menyelesaikan masalah yang diberikan. Siswa diminta mencari solusi dari masalah tersebut berdasarkan pengetahuan yang telah mereka ketahui sebelumnya dan dihubungkan dengan masalah yang sedang dihadapi. Pada tahap ini, guru berperan membimbing kelompok yang sedang melakukan diskusi, berperan sebagai fasilitator, serta berkeliling kelas membantu siswa dengan cara memberikan pertanyaan-pertanyaan dan menginformasikan apa yang dibutuhkan agar siswa mampu merangsang pengetahuan mereka dalam menemukan solusi yang dibutuhkan. Setelah berdiskusi dalam kelompok, perwakilan siswa dari salah satu kelompok mempresentasikan hasil diskusi kelompok, perwakilan siswa dari salah satu kelompok mempresentasikan hasil diskusi kelompknya dan kelompok lain bertugas untuk menanggapi jawaban dari kelompok yang mempresentasikan. Pada tahap diskusi ini, siswa diminta menemukan solusi pemasalahan yang paling tepat secara bersama-sama. Apabila terjadi perbedaan cara penyelesaian suatu masalah, disinilah peran guru sebagai penengah dalam menentukan solusi permasalahan yang paling tepat dan efisien. Pada tahap summarize, siswa dengan dibimbing oleh guru membuat kesimpulan dari pembelajaran yang telah dilakukan. Menyimpulkan solusi permasalahan paling tepat untuk menyelesaikan masalah yang diberikan dan guru bertugas memberikan penguatan dan penegasan kepada siswa tentang materi yang dipelajari pada pertemuan itu.

Selama proses pembelajaran Connected Mathematic Project (CMP) ini, pada pertemuan awal, siswa merasa bingung dan kesulitan dalam mengerjakan Lembar Kerja Siswa (LKS) yang diberikan. Mereka belum terbiasa mengerjakan Lembar Kerja Siswa (LKS) dengan cara mencari sendiri informasi yang dibutuhkan untuk menjawab pertanyaan-pertanyaan yang diberikan, dan siswa ysng kesulitan ketika menghubungkan masalah yang diberikan dengan konsep lama yang sebenarnya telah mereka kuasai sebelumnya.

Pada saat siswa mempresentasikan hasil diskusi kelompoknya ke depan kelas, terlihat siswa masih kesulitan mengungkapkan ide dan gagasannya dengan baik. Hal ini disebabkan karena kebiasaan belajar siswa selama ini yang pasif, lebih banyak sebagai pendengar dan mencatat apa yang ditulis guru serta kurang adanya interaksi antar siswa yang membuat mereka kurang berani dalam mengungkapkan ide tau menyampaikan pertanyaan ketika ada yang belum dipahami. Pada pertemuan selanjutnya, terlihat perubahan yang terjadi dalam proses belajar. Hal ini terlihat dari siswa yang mulai antusias mengikuti pembelajaran. Siswa lebih aktif dalam proses diskusi, mulai berani mengemukakan gagasan dan ide-ide yang sesuai dalam memberikan tanggapan pada jawaban teman yang melakukan presentassi di depan kelas.

Pada kelas kontrol, pembelajaran yang diterapkan adalah model pembelajaran konvensional. Pembelajaran konvensional di sekolah tempat dilakukannya penelitian ini menggunakan metode ekspositori, tanya jawab dan pemberian latihan. Guru menyampaikan materi, memberikan pertanyaan-pertanyaan yang merangsang pemikiran siswa serta memberikan contoh soal. Tugas siswa hanya sebatas mendengarkan, menjawab pertanyaan guru dan mencatat konsep-konsep yang diberikan kesempatan untuk bertanya kepada guru. Setelah guru selesai menyampaikan materi, siswa diberi latihan soal sebagai penguatan.

Proses pembelajaran yang dilakukan di kelas kontrol ini, siswa tidak terlibat secara optimal dan cenderung pasif. Siswa tidak diberi kesempatan untuk bertukar pendapat dengan temannya dalam mengungkapkan ide dan gagasannya di dalam kelas. Dengan demikian siswa cenderung belajar dengan cara menghafal apa yang telah diberikan guru. Namun kelebihan dari kelas kontrol ini adalah siswa dapat 
mengerjakan dengan lancar dan sistematis terhadap soal yang diberikan guru, dengan catatan soal tersebut sesuai dengan contoh yang dijelaskan, maka siswa akan mengetahui kesulitan untuk menyelesaikannya.

Berdasarkan uraian di atas menunjukan bahwa perlakuan yang berbeda menyebabkan terjadinya hasil akhir yang berbeda antara kelas eksperimen yang mendapatkan pembelajaran dengan model Connected Mathematic Project (CMP) dan kelas kontrol yang mendapatkan pembelajaran konvensional. Hal ini dibuktikaan dengan analisis data hasil penelitian, ada perbedaan yang cukup signifikan pada kemampuan pemecahan masalah matematika siswa yang dipengaruhi model pembelajaran Connected Mathematic Project (CMP) dengan kemampuan pemecahan masalah matematika siswa yang dipengaruhi model pembelajaran konvensional. Kemampuan pemecahan masalah matematika siswa yang diajar dengan menggunakan model pembelajaran Connected Mathematic Project (CMP) lebih tinggi dari pada kemampuan pemecahan masalah matematika yang diajar dengan menggunakan model pembelajaran konvensional.

\section{SIMPULAN}

Berdasarkan hasil penelitian, terdapat pengaruh antara model pembelajaran Connected Mathematic Project (CMP) terhadap kemampuan pemecahan masalah matematika. Model pembelajaran yang berprinsip mengembangkan pemahaman penting mengenai konsep, keterampilan, prosedur, dan cara berpikir dan bernalar dalam angka, geometri, pengukuran, aljabar, probabilitas, dan statistik memberikan pengaruh positif terhadap hasil akhir dalam pembelajaran matematika.

\section{DAFTAR RUJUKAN}

Hamzah, A. (2014). Evaluasi Pembelajaran Matematika. Jakarta: Rajawali Pers. Hamzah, A \& Muhlisrarini. (2014). Perencanaan dan Strategi. Jakarta: Rajawali Pers. Hamzah, M. A. (2014). Evaluasi Pembelajaran Matematika. Jakarta: Rajagrafindo Persada.

Lappan, G., dkk. (2002). Getting to Know Connected Mathematics: an Implementation Guide. New Jersey: Prentice Hall. (Diunduh dari http://citeseerx.ist.psu.edu/viewdoc/download?doi=10.1.1.198.5833 \&rep=rep1\&type=pdf, pada 14 mei 2016).

Mulyoko. (2014). Pengaruh Model Pembelajaran Connected Mathematic Project (CMP) Terhadap Kemampuan Representasi Matematis Siswa. (Online). (Diunduh dari https://www.repository. uinjkt.ac.id/dspace/bitstream/.../27631/1/MULYOKO-FITK.pdf, pada 20 mei 2016 ).

NCTM. (2000). Principles and Standards for School Mathematics. Reston. (Diunduh dari https://www.nctm.org/uploadedFiles/Standards_and_Positions/PSSM_ExecutiveSummary.pdf, pada 18 mei 2016 ).

Rohendi, D \& Dulpaja, J. (2013). Connected Mathematic Project (CMP), Model Based On Presentation Media to the Mathematical Connection Ability Junior High School Student, Journal of Education and Practice. Vol. 4. Hal 18.

Sugiyono. (2009). Metode Penelitian Kuantitatif Kualitatif dan R\&D. Bandung: Alfabeta.

Sukardi. (2003). Metodologi Penelitian Pendidikan Kompetensi dan Praktiknya. Jakarta: Bumi Aksara.

Supardi U.S. (2013). Aplikasi Statistika dalam Penelitian: Konsep Statistika yang Lebih Komprehensif. Jakarta: Change Publication. 